\title{
Efektivitas Grass Barrier(Rumput Penghalang) terhadap Pengendalian Erosi Angin di Merapi
}

\author{
Effectiveness of Grass Barriers for Wind Erosion Control on Merapi Mountain \\ Beny Harjadi*, Pranatasi Dyah Susanti \\ Balai Penelitian Teknologi Kehutanan Pengelolaan Daerah Aliran Sungai \\ Jl. Ahmad Yani, Pabelan, PO Box 295, Solo, 57102, Indonesia \\ *Email: adbsolo@yahoo.com
}

Submisi: 27 April 2016; Penerimaan: 8 Februari 2018

\begin{abstract}
ABSTRAK
Bencana erupsi Gunung Merapi tahun 2010 telah mengeluarkan material lebih dari 130 juta $\mathrm{m}^{3}$ dan berdampak pada penimbunan material yang tebal dan tinggi, sehingga menyebabkan kerusakan lahan pekarangan dan pertanian. Setelah dilakukan penambangan, timbunan material berupa batu besar, batu, kerakal, kerikil sampai pasir, maka perlu diupayakan kegiatan RLKT (Rehabilitasi Lahan dan Konservasi Tanah) dengan menggerakkan masyarakat di Desa Kepuharjo. BPPTPDAS Solo telah bekerjasama dengan masyarakat Desa Kepuharjo yang tergabung dalam FPL PALEM (Forum Peduli Lingkungan-Pecinta Alam Lereng Merapi) dengan melakukan RLKT berupa rumput penghalang (Grass Barriers) dan perlakuan pupuk kandang dengan pengamatan erosi permukaan akibat pengaruh angin pada rorak. Tujuan penelitian ini adalah untuk menghitung tingkat efektivitas rumput penghalang terhadap pengendalian erosi angin pada lahan bekas erupsi di Merapi. Hasil yang diperoleh bahwa rumput dan kombinasi dengan pupuk kandang mampu menekan erosi sampai $88 \%$. Jenis rorak yang efektif adalah rorak yang berasal dari ember. Tidak disarankan menggunakan rorak dengan stik di dalamnya karena timbunan partikel tanah disekitar rorak yang tidak stabil, ataupun dengan plastik karena akan mudah robek.
\end{abstract}

Kata kunci: Rumput penghalang; pupuk kandang; rorak; erosi permukaan; erosi angin

\section{ABSTRACT}

Mount Merapi eruption in 2010 that discharged more than 130 million $\mathrm{m}^{3}$ of landfill material brought impact on the thickness and height of caused damage to the yard and agricultural land. After mining heap of materials in the form of boulders, stones, gravels, and gravel to sand, RLKT activities (Rehabilitation and Soil Conservation) needs to be pursued to mobilize the people in the village of Kepuharjo. Cooperation between BPTKPDAS Solo with Kepuharjo Village community is incorporated in FPL PALEM (Environmental Care Forum Merapi Slope-Nature Lovers) by performing RLKT barrier in the form of grass planting (Grass Barriers) and manure treatment with the observation of surface erosion due to the effects of wind on the rorak. The purpose of this study was to quantify the effectiveness of grass barrier for wind erosion control at the land formerly affected by eruption at Merapi Mountain. The results show that the combination of grass and manure was able to suppress the erosion up to $88 \%$. Effective rorak types were derived from bucket and it is not recommended that rorak includes a stick for a heap of unstable soil particles. Therefore, the usage of plastic is not suggested as it is easily torn.

Keywords: Grass barriers; manure; rorak; surface erosion; wind erosion

\section{PENDAHULUAN}

Bencana Gunung Merapi pada tahun 2010 mengalami pengulangan letusan reguler yang terbesar selama100 tahun terakhir (Badan Geologi, 2013) dan memuntahkan 130 juta $\mathrm{m}^{3}$ material gunung api (Sumarti dkk., 2014). Hasil penelitian Hanudin (2011) dalam Susanti (2013) menunjukkan bahwa letusan Gunung Merapi pada akhir Oktober 2010 tersebut bersifat efusif dan eksplosif serta memiliki 3 fase material diantaranya: (1) fase padat yang terdiri dari fraksi, debu, pasir, krakal dan batu; (2) fase gas berupa awan panas; (3) fase cair berupa lahar. Hanudin (2011) menambahkan bahwa fase cair, akan menimbulkan dampak kerusakan terparah dibandingkan dengan kedua fase yang lain. Material erupsi berdampak buruk pada penutupan lahan pertanian masyarakat. Menurut Tarigan (2015) ketebalan abu vulkanik pascaletusan 
yang menutupi lahan pertanian dapat diklasifikasikan menjadi 4 kelas, yaitu: tipis (ketebalan $<2 \mathrm{~cm}$ ), sedang (ketebalan $2-5 \mathrm{~cm}$ ) dan tebal $(>5 \mathrm{~cm}$ ).

Menurut Idjudin dkk. (2014) lahan pertanian yang dekat dengan puncak Gunung Merapi pada radius 5 km, mengalami kerusakan berat yang dipengaruhi oleh perubahan aliran lahar karena dasar sungai yang tertimbun oleh material Merapi, kelokan sungai serta tebing sungai yang rendah. Kerusakan pada lahan Merapi disamping mempengaruhi kondisi kesuburan tanah, juga memperlihatkan adanya alur aliran permukaan bahkan sampai terjadi erosi parit hingga erosi tebing (Idjudin dkk., 2014). Menurut Hardjowigeno (2010), agen erosi permukaan tanah yang menyebabkan berpindahnya partikel tanah dari lereng atas ke lereng bawah salah satunya adalah pengaruh air maupun angin.

Kegiatan rehabilitasi pascaerupsi pada kawasan ini sangat diperlukan, meskipun pada radius $5 \mathrm{~km}$ tersebut sudah tidak diperkenankan menjadi wilayah permukiman oleh pemerintah daerah setempat dan hanya diperkenankan untuk kegiatan pertanian, perkebunan dan kehutanan. Di sisi lain untuk area dengan radius di atas $5 \mathrm{~km}$, area ini diperbolehkan untuk berbagai kegiatan dan aktivitas masyarakat termasuk di dalamnya pembangunan permukiman.

Upaya pemulihan lahan yang rusak akibat erupsi Gunung Merapi dapat dilakukan dengan berbagai cara baik sipil teknis (mekanik), vegetatif maupun kimia (Rahayu dkk., 2014). Kegiatan rehabilitasi dan konservasi lahan yang bersifat kerjasama dengan masyarakat, akan sangat membantu pemulihan kesuburan lahan pascaerupsi. Rumput penghalang atau grass barrier, dapat digunakan sebagai salah satu metode rehabilitasi lahan secara vegetatif, terutama untuk mencegah timbulnya erosi yang lebih lanjut pada wilayah ini. Menurut penelitian Safriani dkk. (2017), penggunaan rumput pait dan rumput alang-alang, mampu menahan laju erosi. Berdasarkan hal tersebut, penelitian ini bertujuan mengetahui tingkat efektifitas rumput penghalang untuk pengendalian erosi permukaan yang disebabkan oleh angin.

\section{METODE PENELITIAN}

\section{Lokasi Penelitian}

Penelitian ini dilakukan dengan membangun demplot penelitian yang berada di Desa Kepuharjo, Kecamatan Cangkringan, Kabupaten Sleman Daerah Istimewa Yogyakarta. Menurut Harjadi dan Susanti (2014), wilayah ini berada pada wilayah Sub DAS Kuning dan Sub Gendol serta masuk dalam DAS Opak-Oyo. Lokasi demplot terletak pada $110^{\circ} 19^{\prime} 55^{\prime \prime}$ BT - 110 $30^{\prime} 17^{\prime \prime}$ BT dan 7033'40" LS - 7050'05" LS (Gambar 1).

\section{Bahan dan Alat}

Pengamatan di lapangan menggunakan peralatan oven untuk mengeringkan sampel erosi dalam keadaan basah dan timbangan untuk menimbang bobot partikel tanah. Pengeringan dengan menggunakan oven merk 200C Desktop buatan dari China yang mampu mengeringkan dari suhu $10{ }^{\circ} \mathrm{C}$ sampai $200{ }^{\circ} \mathrm{C}$. Sedangkan timbangan menggunakan neraca analitik digital Mettler dengan ketelitian 0,1 mg dengan merk Timbangan Analitik $220 \mathrm{~g}$ AS220 R1 buatan Eropa.

\section{Metode}

Perlakuan penelitian terdiri dari 2 Plot sebagai demplot penelitian, dengan 3 jenis rorak yang berbeda, 2 jenis rumput dan pupuk kandang berbahan dasar kotoran sapi yang sudah terdekomposisi. Pengamatan erosi angin ditampung pada rorak yang terdiri dari 3 macam rorak yaitu: 1) Rorak Ember, 2) Rorak Plastik, dan 3) Rorak Stik. Masing-masing rorak dipakai untuk mengamati tiga Perlakuan Guludan yaitu: 1) Rumput akar wangi (Vetiveria zizanioides), 2) Gamal (Gliricidia sepium), 3) Guludan saja (sebagai kontrol). Masingmasing Plot dilakukan perlakuan dengan pupuk kandang dengan dosis $5 \mathrm{~kg}$ per tanaman dan sebagai kontrol adalah lahan yang tidak menggunakan pupuk kandang.

Teknik pengumpulan data erosi tanah di lapangan akibat perpindahan partikel tanah oleh angin dilakukan dengan pengamatan erosi tanah pada Plot I dan Plot II menggunakan rorak. Rorak dibangun pada berbagai perlakuan teknik konservasi yang telah dilakukan pada plot terbangun serta lahan kosong sebagai kontrol. Pengukuran erosi dapat diketahui dari tanah yang tertampung ke dalam rorak sebagai tanah yang tererosi, dengan menimbang berat kering tanah.

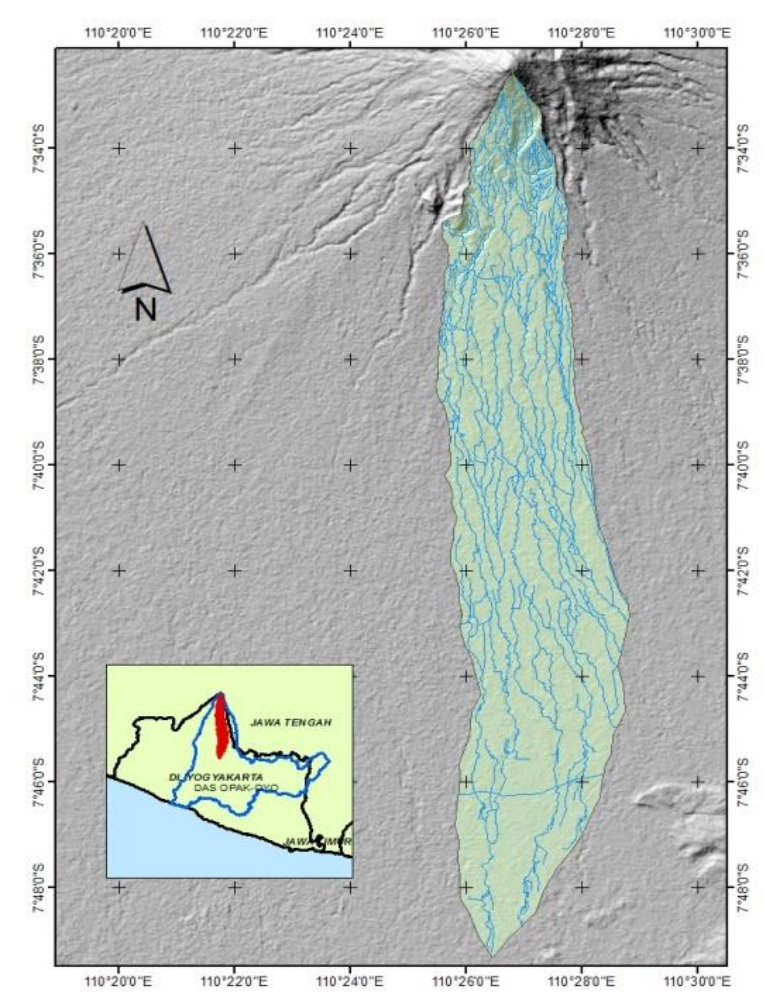

Gambar 1. Sub DAS Kuning dan Sub Das Gendol, DAS OpakOyo (Harjadi dan Susanti, 2014) 

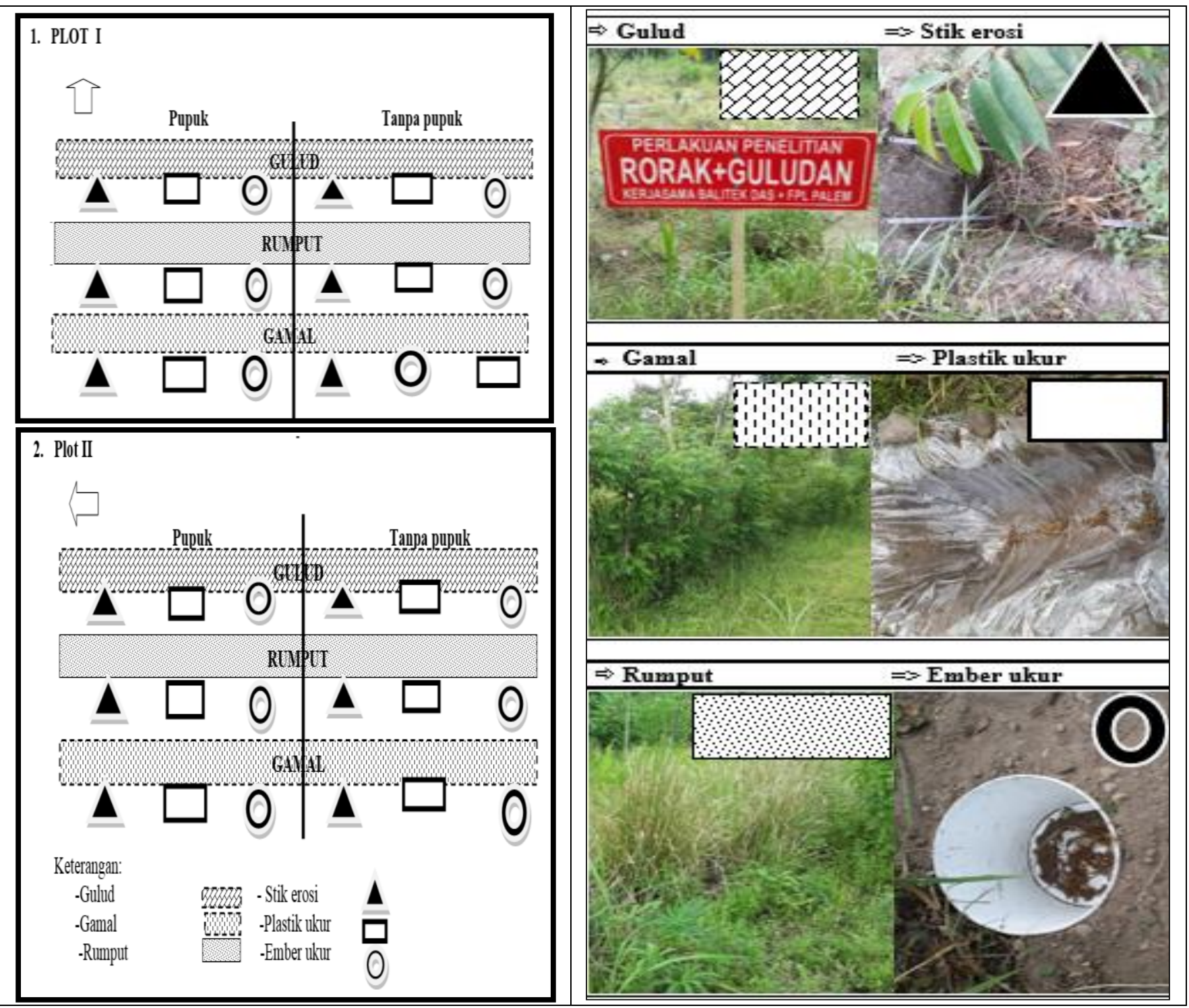

Gambar 1. Demplot RLKT Plot I dan Plot II dengan perlakuan guludan, gamal dan rumput akar wangi pada tiga jenis rorak (stik erosi, plastik dan ember)

Metode konservasi yang digunakan adalah metode vegetatif (rumput gajah, rumput vetiver, gamal); mekanik (guludan); kimia (bahan pembenah tanah dan kompos). Rorak yang menggunakan stik dan plastik dibangun sejajar kontur atau memotong lereng dengan ukuran panjang $1 \mathrm{~m}$ lebar $50 \mathrm{~cm}$ dan dalam $60 \mathrm{~cm}$, sedangkan ember yang digunakan untuk teknik penampungan tanah berukuran tinggi $47 \mathrm{~cm}$ dan diameter $30 \mathrm{~cm}$. Gambar dan desain demplot penelitian dapat dilihat pada Gambar 2.

\section{HASIL DAN PEMBAHASAN}

Selama satu bulan pengamatan terhadap erosi angin, diperoleh informasi bahwa terdapat beberapa variasi nilai erosi yang ditimbulkan oleh angin pada lokasi penelitian. Hal ini menunjukkan bahwa terdapat pengaruh penanaman grass barrier terhadap besarnya erosi yang ditimbulkan. Hasil pengamatan dapat terlihat pada Tabel 1.

Berdasarkan data tersebut, dapat diketahui bahwa nilai erosi tanah yang disebabkan oleh angin antar perlakuan terdapat perbedaan yang mencolok, terutama pada jebakan erosi menggunakan stik erosi. Nilai erosi yang tinggi diakibatkan adanya longsoran kecil pada rorak yang terbangun, sehingga terjadi bias antara tanah yang masuk ke dalam rorak karena erosi angin dengan tanah yang masuk karena longsor pada rorak. Berdasarkan hasil tersebut, maka tidak disarankan pengukuran erosi menggunakan rorak dengan stik yang dimasukkan ke dalam rorak, khususnya pada tanah-tanah yang labil atau agregasinya kurang kuat. Rata-rata erosi angin pada berbagai perlakuan dengan data erosi stik, erosi pada ember, erosi pada plastik ditunjukkan pada Gambar 2. 
Tabel 1. Hasil pengamatan erosi angin di Plot I dan Plot II pada berbagai perlakuan

\begin{tabular}{|c|c|c|c|c|}
\hline Plot perlakuan & Grass barrier & Tipe rorak & $\begin{array}{c}\text { Tanpa pupuk } \\
\text { (ton/ha/th) }\end{array}$ & $\begin{array}{l}\text { Dengan pupuk } \\
\text { (ton/ha/th) }\end{array}$ \\
\hline \multirow[t]{9}{*}{ Plot I } & Gamal & Plastik & 1,6 & 1,2 \\
\hline & & Ember & 1,6 & 1,5 \\
\hline & & Stik & 1,8 & 1,3 \\
\hline & Rumput & Plastik & 1,3 & 1,4 \\
\hline & & Ember & 1,7 & 1,2 \\
\hline & & Stik & 2,3 & 0,5 \\
\hline & Talud & Plastik & 1,6 & 1,9 \\
\hline & & Ember & 1,3 & 1,2 \\
\hline & & Stik & 1,8 & 1,8 \\
\hline \multirow[t]{9}{*}{ Plot II } & Gamal & Plastik & 1,8 & 2,3 \\
\hline & & Ember & 1,3 & 3,0 \\
\hline & & Stik & 2,9 & 2,3 \\
\hline & Rumput & Plastik & 1,5 & 1,1 \\
\hline & & Ember & 1,7 & 3,4 \\
\hline & & Stik & 4,1 & 1,3 \\
\hline & Talud & Plastik & 1,7 & 1,7 \\
\hline & & Ember & 1,3 & 4,2 \\
\hline & & Stik & 0,9 & 1,1 \\
\hline
\end{tabular}

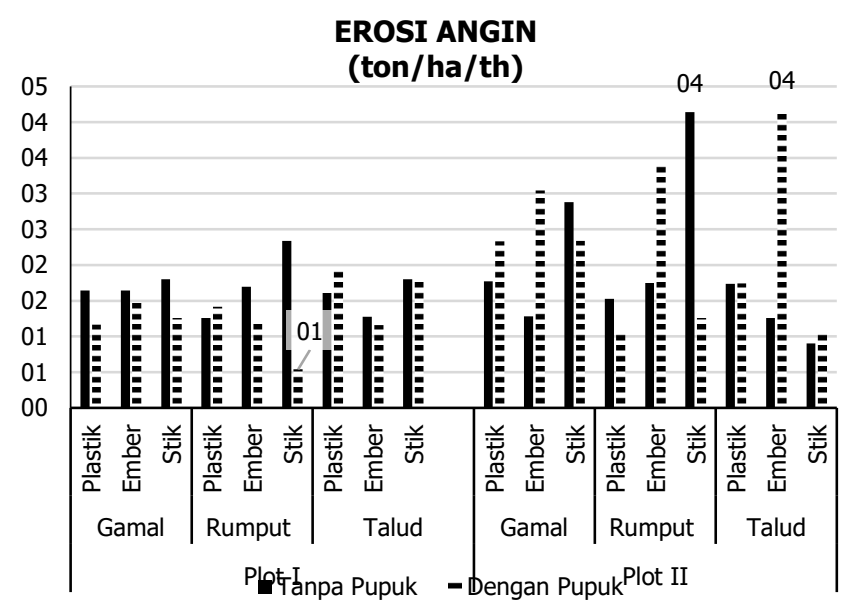

Gambar 3. Erosi angin di rorak pada perlakuan grass barrier dan pupuk

Gambar 2 menunjukkan bahwa rata-rata erosi angin lebih tinggi terjadi pada Plot II, dimana plot tersebut belum terpelihara sebaik Plot I. Nilai tertinggi erosi terjadi pada perlakuan talud dengan pupuk. Hal ini disebabkan karena tidak adanya tanaman penahan sehingga tanah lebih mudah tererosi terbawa oleh angin meskipun tanah tersebut telah diberi perlakuan pupuk organik. Plot I dengan pengelolaan lahan yang lebih intensif, terlihat bahwa rata-rata nilai erosi angin lebih kecil pada perlakuan vegetasi (rumput dan gamal) dibandingkan talud (tanpa vegetasi). Erosi angin terendah 0,54 ton/ha/th (P.I) yang tertampung pada rorak dengan stik dan rumput vertiver atau mampu menahan erosi sebesar 88\%. Nilai erosi tertinggi sebesar 4,17 ton/ha/th (P.II) berada pada perlakuan tanah yang tertampung pada rorak ember dan tanpa rumput penghalang. Hasil yang sama juga diperoleh Safriani dkk. (2017), bahwa pada penanaman dengan jenis rumput pait dapat memilki laju erosi yang lebih rendah yaitu 0,451 ton/ha/th dibandingkan dengan tanah tanpa rumput yaitu sebesar 2,217 ton/ha/th pada tanah dengan kemiringan $15^{\circ}$.

Analisis sidik ragam dapat dilihat pada Tabel 2. Tabel 2 menunjukkan bahwa hanya interaksi antara lokasi dan pupuk kandang yang berpengaruh pada erosi. Berdasarkan hal tersebut dapat diketahui bahwa Tabel 2. Analisis sidik ragam 2 blok dengan perlakuan 3 macam rorak dan 2 jenis grass barrier

\begin{tabular}{ccccccc} 
SK & Perlakuan & $\mathrm{db}$ & $\mathrm{JK}$ & $\mathrm{KT}$ & Fhit & Ftab-5\% \\
\hline$\cdot$ & & & 1,80 & & & \\
FK & Faktor koreksi & & 3,90 & & & \\
A & Lokasi (L) & 1 & 36,17 & 36,17 & 2,65 & $-(242,0)$ \\
B & Grass barrier (GB) & 2 & 28,80 & 14,40 & 1,06 & $--(19,4)$ \\
C & Pupuk kandang (PK) & 5 & 38,60 & 7,72 & 0,57 & $--(4,74)$ \\
AB & L $\times$ GB & 2 & 419,16 & 209,58 & 15,37 & $--(19,4)$ \\
AC & L $\times$ PK & 5 & 536,49 & 107,30 & 7,87 & $*-74)$ \\
BC & GB $\times$ PK & 10 & 133,63 & 13,36 & 0,98 & $--) 2,98)$ \\
ABC & L $\times$ GB $\times$ PK & 10 & 136,37 & 13,64 & & \\
\hline
\end{tabular}


pengaruh pupuk kandang sangat nyata untuk penguatan agregasi tanah yang sifatnya lepas pada tanah psamment Andisols di Merapi. Dengan semakin mantapnya agregasi tanah yang ditunjukkan dengan struktur tanah yang semakin matang dan tidak mudah lepas, tanah tidak mudah dipindahkan oleh pengaruh erosi angin. Erosi yang tertampung pada rorak seringkali terganggu oleh runtuhnya tanah yang lepas karena tekstur yang kasar dan struktur granular yang lemah dari dinding rorak. Gangguan juga terjadi karena gangguan pengolahan tanah, penyiangan tanaman, dan oleh injakan hewan atau manusia pada guludan.

Grass barrier memberikan pengaruh hampir berbeda nyata karena pengaruh dari rumput, gamal dan kontrol tidak nampak nyata di lapangan, karena kondisi lahan sudah rapat ditutupi tanaman utama sengon dan tanaman bawah rumput-rumputan yang rapat. Sehingga pengaruh erosi angin yang dapat ditangkap di rorak tidak berbeda nyata.

Penelitian ini menunjukkan bahwa pada plot bekas erupsi Merapi tahun 2010 yang belum dikelola dengan baik, akan menunjukkan nilai erosi yang lebih tinggi dibandingkan dengan lahan yang sudah dikelola dengan baik memalui penanaman grass barrier. Selain itu penambahan pupuk kandang juga dapat mendukung rehabilitasi lahan pascaerupsi. Diharapkan rehabilitasi lahan secara vegetatif dan mekanik ini dapat dilakukan pada lahan Merapi pascaerupsi.

\section{KESIMPULAN}

Grass barrier (rumput penghalang) berupa Gamal (Gliricidia sepium sp.) dan rumput Akar wangi (Vetiveria zizanioides $s p$ ) sangat efektif digunakan sebagai salah satu metode konservasi secara vegetatif pada lahan pascaerupsi Merapi. Metode tersebut, mampu mengurangi tingkat erosi oleh angin sebesar $88 \%$. Metode secara vegetatif ini, akan lebih optimal dengan pemberian pupuk kandang, untuk perbaikan agregasi tanah. Sangat disarankan menggunakan rorak yang berasal dari ember plastik yang terukur, dibandingkan menggunakan rorak plastik maupun stik, karena lebih awet, akurat dan lebih mudah dalam melakukan pengamatan laju erosi pada suatu lahan.

\section{UCAPAN TERIMA KASIH}

Ucapan terimakasih disampaikan kepada semua pihak yang berperan dan terkait dengan kegiatan pengembangan penelitian di Desa Kepuharjo, Kecamatan Cangkringan, Kabupaten Sleman. Terutama teman-teman Teknisi dan Peneliti dari Balitek DAS (BPTKPDAS Solo) dan FPL PALEM (Forum Peduli Lingkungan - Pecinta Alam Lereng Merapi) masyarakat Desa Kepuharjo, serta aparat dan perangkat yang bertugas di Desa Kepuharjo, Kecamatan Cangkringan serta Dinas Kehutanan Kabupaten Sleman.

\section{DAFTAR PUSTAKA}

Badan Geologi (2013). Modul Wajib Latih Penanggulangan Bencana Gunung Merapi 2013. Kementrian ESDM. Yogyakarta.

Hanudin, E. (2011). Pendekatan Agroekologi dalam Pemulihan Lahan Pertanian Pasca Erupsi. Prosiding Semnas Upaya Pemulihan Lahan Akibat Erupsi Gunungapi. Universitas Sebelas Maret (UNS). Surakarta.

Harjadi, B. \& Susanti. P. D. (2014). Analisis Status Hara dan Bahan Letusan pada Lahan Lereng Merapi Di DAS OpakOyo. Prosiding Seminar Nasional Pengelolaan DAS Terpadu untuk Kesejahteraan Masyarakat. BPTKPDAS dan Universitas Brawijaya. Malang, 30 September - 1 Oktober 2014.

Hardjowigeno, S. (2010). IImu Tanah. Jakarta: Akademika Pressido.

Idjudin, A. A., Erfandi, M. D., \& Sutono, S. (2014). Teknologi Peningkatan Produktivitas Lahan Endapan Volkanik Pasca Erupsi G. Merapi. http://balittanah.litbang.pertanian. go.id /ind/dokumentasi/lainnya/Teknologi\%20Peningkatan\%20 Prod\%20Lhn\%20Endpn\%20Volk\%20Pasca\%20Erupsi\%2 0G.\%20Merapi\%20_Pa\%20Abas_.pdf. [4 Februari 2015].

Rahayu, Ariyanto, D. P., Komariah, \& Hartati. S. (2014). Dampak erupsi Gunung Merapi terhadap lahan dan upaya pemulihannya. Jurnal Caraka Tani, XXIX(1), 61-72.

Safriani, Jayanti, D. S., \& Syahrul (2017). Pengandalian erosi secara vegetatif menggunakan rumput pait (Axonopus compressor) dan rumput alang-alang (Imperata cylindrical) pada tanah ordo ultisol. Jurnal Ilmiah Mahasiswa Pertanian Unsyiah, 2(2), 396-403.

Sitinjak, L., Purba, E., \& Putri, L. A. P. (2015). Identifikasi periode kritis persaingan dengan uji interval bebas gulma pada dua varietas tanaman sorgum (Sorghum bicholor (L.) Muench) dilihat pada aspek pertumbuhan vegetatif. Jurnal Ilmu Pertanian Kultivar, 9(1), 9-17.

Sumarti, S., Aisyah, N., Sadono, F., Yulianto, Nurmanaji, A., Sopari, A., \& Triyono (2013). Aktivitas Gunung Merapi periode Mei-Agustus 2013. Buletin Merapi, 12(2).

Susanti. P. D. (2013). Konservasi vegetatif pada lahan marginal pascaerupsi Merapi. Prosiding Seminar Nasional Himpunan IImu Tanah Indonesia Pemanfaatan Lahan Marginal Berbasis Sumberdaya Lokal untuk Mendukung Ketahanan Pangan Nasional. Purwokerto, 8 Juni 2013: 52-62.

Tarigan, A. (2015). Rehabilitasi lahan pertanian tertutup abu vulkanik erupsi Gunung Sinabung. Jurnal Pertanian Tropik, 2(26), 220-227. 